\title{
The effects of low-dose gamma-irradiation on the wholesomeness of mangoes (Mangifera indica) as determined by short-term feeding studies using rats
}

\author{
BY G. M. J. HORTON* \\ Faculty of Veterinary Science, University of Pretoria, PO Box $125^{80}$, \\ Onderstepoort or 1o, South Africa \\ (Received 25 March 1975 - Accepted 29 May 1975)
}

\begin{abstract}
I. A control diet and diets containing $150 \mathrm{~g}$ non-irradiated or $150 \mathrm{~g}$ irradiated mangopulp/kg were given to female rats from day 15 of the gestation period until weaning in trials $\mathbf{I}$ and 2 , and from $40 \mathrm{~d}$ before mating until $28 \mathrm{~d}$ post weaning in trial 3 .

2. Food intake and dry-matter digestibility were similar with all diets.

3. There were no significant differences between animals given the different dietary regimens in the daily body-weight changes of weanling males, pups, nursing females or females during the immediate postlactation period.

4. No differences in haematological or blood chemistry values were found which could be attributed to the ingestion of irradiated mangoes. There was no evidence for the presence of any toxic substances in the irradiated-mango-pulp diet.

5. Gross pathological observations revealed no aberrations which could be related to the ingestion of irradiated mangoes.

6. It may be concluded that the wholesomeness of mangoes was not affected by gammairradiation at a dose of $75 \mathrm{krd}$.
\end{abstract}

Low-dose gamma-irradiation has been shown to reduce spoilage and therefore extend the 'shelf-life' of some perishable foods (Reber, Raheja \& Davis, 1966). The increasing popularity in Europe of late-maturing, fibreless mangoes (Mangifera indica) grown in South Africa, and the desirability of using slow but inexpensive refrigerated marine freight, led to studies of the feasibility of irradiating mangoes to prolong 'shelflife'. The primary objective of irradiation was to reduce the damage caused by the mango weevil (Sternochetus mangiferae F.) and the two main fungal diseases, soft brown rot (Hendersonia creberimma) and anthracnose (Colletotrichum gloeosporioides).

The results of studies done by the South African Atomic Energy Board at Pelindaba have indicated the optimum conditions and irradiation dosage necessary for the preservation of mangoes and the control of the three parasitic diseases mentioned previously (A. C. Thomas, personal communication). The 'shelf-life' of irradiated mangoes after storage for 4 weeks at $10-I^{\circ}$ was extended, owing to both the control of parasitic diseases and a slight delay in ripening.

The present study was undertaken to obtain a suitable diet for use in long-term, multi-generation studies in the rat designed to assess the wholesomeness of irradiated mangoes. Wholesomeness has been defined as the suitability of foods for human consumption in terms of potential toxicity and nutritional adequacy (Read, 1960).

* Present address: Department of Animal Science, University of Saskatchewan, Saskatoon, Saskatchewan $\mathrm{S}_{7} \mathrm{~N}$ oWO, Canada. 
Table 1. Composition ( $\mathrm{g} / \mathrm{kg}$ ) of the experimental diets with and without gamma-irradiated* or non-irradiated mango-pulp given to rats

\begin{tabular}{|c|c|c|}
\hline \multirow[b]{2}{*}{ Ingredients } & \multicolumn{2}{|c|}{ Diet } \\
\hline & Control & With mango-pulp \\
\hline Mango-pulp & 一 & $150 \cdot 0$ \\
\hline Yellow maize meal & $520 \cdot 0$ & 440.4 \\
\hline Rolled oats & $60 \cdot 0$ & $50 \cdot 8$ \\
\hline Wheaten bran & $120 \cdot 0$ & IOI. 6 \\
\hline Lucerne meal & $35 \cdot 0$ & $29 \cdot 6$ \\
\hline Groundnut oilcake meal & $30 \cdot 0$ & $25 \cdot 4$ \\
\hline Fish meal & 100.0 & 84.7 \\
\hline Carcass meal & $65 \cdot 0$ & $55 \cdot 1$ \\
\hline Skim-milk powder & 50.0 & $42 \cdot 4$ \\
\hline Mineral mixture $\dagger$ & 16.0 & I6.0 \\
\hline Vitamin mixturef & $4 \cdot 0$ & $4 \cdot 0$ \\
\hline
\end{tabular}

* Total dose $75 \mathrm{krd}$; for details of irradiation procedure, see below.

$\uparrow$ Contained (g): $\mathrm{CaHPO}_{4} \cdot 2 \mathrm{H}_{2} \mathrm{O} 75 \cdot 00, \mathrm{NaCl} 22 \cdot 10, \mathrm{MgSO}_{4} \cdot 7 \mathrm{H}_{2} \mathrm{O} 8 \cdot 70$, ferric citrate pentahydrate $5 \cdot 50, \mathrm{MnSO}_{4} \cdot \mathrm{H}_{2} \mathrm{O} 0.52, \mathrm{KI} 0.08, \mathrm{CuSO}_{4} \cdot 5 \mathrm{H}_{2} \mathrm{O} 0.07$.

$\mp$ Contained (g/kg mixture): Rovimix A-500 (150 mg retinol/g) 2.5, Rovimix D-400 (ro mg cholecalciferol/g) 0.2, Rovimix E ( $68 \mathrm{mg} \alpha$-tocopherol equivalent/g) (Roche Products Ltd, Welwyn Garden City, Herts., UK) 60.0 , menaphthone $2 \cdot 25$, thiamin $\mathrm{HCl} 2 \cdot 0$, riboflavin $3 \cdot 0$, calcium pantothenate $3 \cdot 0$, pyridoxine $\mathrm{HCl} \mathrm{r} \cdot 5$, nicotinic acid 4.5 , biotin 0.04 , pteroylmonoglutamic acid 0.09 , cyanocobalamin $0 \cdot 00135$, myo-inositol $5^{\circ} \circ, p$-aminobenzoic acid $5^{\circ} \circ$.

\section{EXPERIMENTAL}

\section{Animals}

Hybrid female rats $\left(B D V \times\right.$ BDIX $\left.F_{I}\right)$ obtained from the South African Bureau of Standards (Pretoria) were used in each of three consecutive reproduction trials. Pregnant, ' 3 rd-litter' females weighing about $34^{\circ} \mathrm{g}$ were introduced to the dietary regimens on the 15 th day of gestation in trials $\mathrm{I}$ and 2 . Day o of gestation was taken as the mid-point of a $3 \mathrm{~d}$ period of mating. In trial 3 , virgin females weighing about $260 \mathrm{~g}$ and young males were maintained on their respective treatment diets from $40 \mathrm{~d}$ before mating. All females were housed in individual breeding cages.

Weanling male offspring, weighing about $56 \mathrm{~g}$, from the three reproduction trials (i.e. $\mathrm{BDV} \times \mathrm{BDIX}$ F2-hybrids) were used for food utilization, haematological, blood chemistry and pathological studies in three consecutive trials. The animals were housed in individual metabolism cages from $26 \mathrm{~d}$ of age for $28 \mathrm{~d}$, and were maintained throughout on the diet given to their parents.

All animals were allowed free access to food and water. The animal room was maintained at a temperature of $2 \mathrm{I} \pm \mathrm{I}^{\circ}$ and relative humidity $50 \pm 5 \%$.

\section{Diets}

The control diet was formulated according to (US) National Research Council (1972) recommendations. Either irradiated or non-irradiated mangoes replaced I $5 \circ \mathrm{g} / \mathrm{kg}$ control diet, as indicated in Table I. The late-maturing Kent variety of mango was selected for these studies. The irradiation was done in the research loop of a ${ }^{60} \mathrm{Co}$ package-irradiation plant (Atomic Energy of Canada Ltd, PO Box 6300, Station 
Table 2. Chemical composition ( $\mathrm{g} / \mathrm{kg}$ ) of the experimental diets with and without gamma-irradiated ${ }^{*}$ or non-irradiated mango-pulp given to rats

\begin{tabular}{|c|c|c|c|}
\hline & \multicolumn{3}{|c|}{ Diet $f$} \\
\hline & \multirow[b]{2}{*}{ Control } & \multicolumn{2}{|c|}{ With mango-pulp } \\
\hline & & Non-irradiated & Irradiated \\
\hline Dry matter & 892 & 775 & 775 \\
\hline $\begin{array}{l}\text { Crude protein (nitrogen } \\
\times 6.25 \text { ) }\end{array}$ & 208 & I 77 & 176 \\
\hline Crude fibre & $45^{\circ} 4$ & $38 \cdot 4$ & $38 \cdot 5$ \\
\hline Diethyl ether extract & 40.9 & $39 \cdot 4$ & $39 \cdot 3$ \\
\hline Calcium & 14.3 & II $\cdot \mathrm{I}$ & $I I \cdot I$ \\
\hline Phosphorus & $9 \cdot 3$ & $8 \cdot 2$ & $8 \cdot 3$ \\
\hline
\end{tabular}

J, Ottawa, Canada) located at Pelindaba. The dosage rate was $14 \mathrm{krd} / \mathrm{h}$, to a total dose of $75 \mathrm{krd}$. After storage for 4 weeks at $10-\mathrm{II}^{\circ}$ the mangoes (both irradiated and non-irradiated) were allowed to ripen at $2 \mathrm{I}^{\circ}$. The flesh was then pulped and stored at $-15^{\circ}$. Sufficient food for a period of $3-5 \mathrm{~d}$ was prepared as required and stored at $6^{\circ}$.

Moisture, crude protein (nitrogen $\times 6 \cdot 25$ ), crude fibre, diethyl ether extract, calcium and phosphorus analyses of the diets were done using the methods recommended by the Association of Official Agricultural Chemists (1965). The chemical composition of the diets is given in Table 2 .

\section{Digestibility and voluntary food consumption}

Food intake of the weanling, F2-hybrid, male rats was measured during days 24-28 of each $28 \mathrm{~d}$ trial period. The animals were offered sufficient food twice daily at 08.00 and 16.00 hours so that no less than $20 \%$ was refused. Refusals and spilled food were removed and weighed each day before the morning feed. The apparent dry matter (DM) digestibility was measured over the same time period.

\section{Body-weight change}

The weanling rats in the metabolism cages were weighed three times/week over a $28 \mathrm{~d}$ period starting $5 \mathrm{~d}$ after weaning.

Both mothers and pups in the reproduction trials were weighed immediately after birth and subsequently three times/week until weaning at 2I d of age. All animals were weighed on a standard time schedule. Daily body-weight changes were estimated as the regression coefficient of body-weight $v$. time.

\section{Litters}

The total number of pups born/litter was recorded. No differentiation was made between still-born pups and those that died shortly after birth. Pups were raised in litters of eight (four male and four female, where possible) and weaned at $2 \mathrm{r} \mathrm{d}$ of age; at $26 \mathrm{~d}$ of age selected males were placed in metabolism cages. 


\section{Haematology and blood chemistry}

Mixed arterial and venous blood was collected from rats anaesthetized with diethyl ether, after the jugular vein and carotid artery had been severed with a single stroke of a sharp blade. Blood samples collected individually from all the weanling rats on completion of the metabolism trials at $54 \mathrm{~d}$ of age were analysed for the following: haemoglobin concentration, erythrocyte count, packed cell volume, mean corpuscular volume, total leucocyte count, differential leucocyte count, serum aspartate aminotransferase (AAT) $(E C$ 2.6. I. I) activity and blood glucose concentration.

Six parent females from each dietary regimen in reproduction trial 3 were killed $28 \mathrm{~d}$ post weaning. Blood samples were collected and blood urea concentration was determined, as well as the previously mentioned estimations.

Haemoglobin concentration was determined using a haemoglobinometer (Coulter Electronics, Hialeah, Florida, USA). Erythrocyte count, packed cell volume, mean corpuscular volume and total leucocyte count were determined using a Coulter Counter (Model FN; Coulter Electronics). The settings used were as follows: threshold 7 , attenuation 0.500 , aperture 32 . The differential leucocyte count was estimated by the microscopic classification of at least roo leucocytes/sample. Blood glucose concentration was determined by the method of Werner, Rey \& Wielinger (1970), AAT activity was measured at $25^{\circ}$ as described by Karmen (I955) and blood urea by the photometric method described by Fawcett $\&$ Scott (1960).

Gross pathological examinations were made for all slaughtered animals.

\section{Experimental design}

The three diets described in Tables I and 2 were compared in randomized-block experimental designs. Results from all three trials using weanling male rats were pooled, as were results from reproduction trials $\mathrm{I}$ and 2.

Measurements of voluntary food consumption and daily body-weight change, as well as haematological, blood chemistry and gross pathological examinations were done using thirteen male weanling rats/dietary regimen in each trial. The apparent digestibility of the diets was measured in each trial using four rats/diet.

Fifteen female rats/dietary regimen were used in each reproduction trial, but several were found not to be pregnant. Pooled results from trials I and 2 represent the mean of fifteen determinations for the control group and sixteen and fifteen determinations for groups offered the non-irradiated and irradiated diets respectively. When virgin females were used in trial 3 , eight, eleven and ten animals given the control, non-irradiated and irradiated diets respectively were found to be pregnant. Haematological, blood chemistry and gross pathological examinations were done using six randomly selected parent females/dietary regimen, $28 \mathrm{~d}$ post weaning in trial 3 .

Analysis of variance and mean comparisons by Scheffe's test were made for all results according to the methods described by Snedecor \& Cochran (1967). The computations were done using an IBM 360 computer. 
Table 3. Voluntary food consumption, dry matter (DM) digestibility, body-weight at start of trial, and growth rate of weanling male rats during a $28 d$ period when they were given diets with or without 150 g gamma-irradiated* or non-irradiated mango-pulp $/ \mathrm{kg}$

(Mean values with their standard errors; no. of determinations in parentheses)

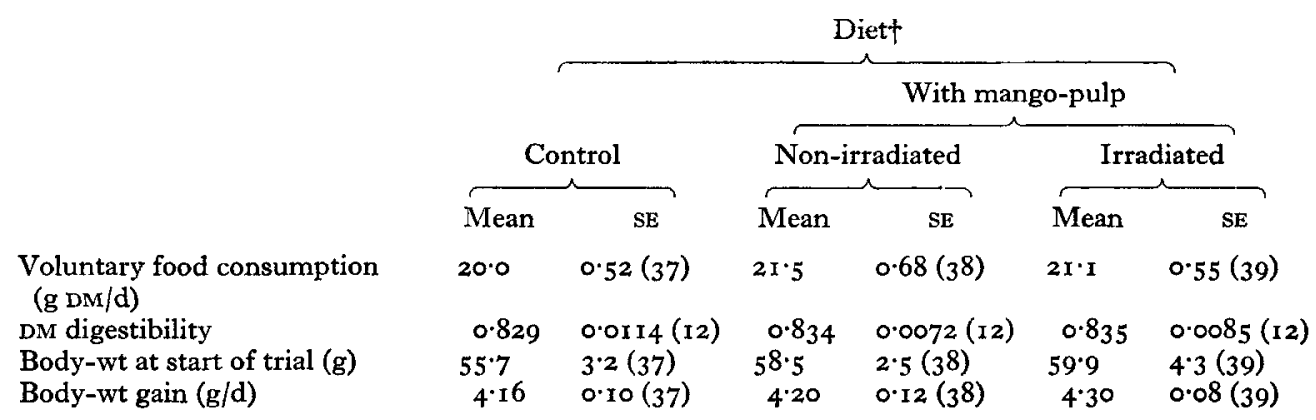

* Total dose $75 \mathrm{krd}$; for details of irradiation procedure, see p. 68 .

$\dagger$ For details, see Tables $\mathrm{I}$ and 2.

Table 4. Trials I and 2. Litter size, body-weight gain of rat pups to weaning, and bodyweight change of nursing mothers* during the $2 \mathrm{I} d$ lactation period, when they were given diets with or without $15 \circ \mathrm{g}$ gamma-irradiated $\dagger$ or non-irradiated mango-pulp $/ \mathrm{kg}$

(Mean values with their standard errors; no. of litters in parentheses)

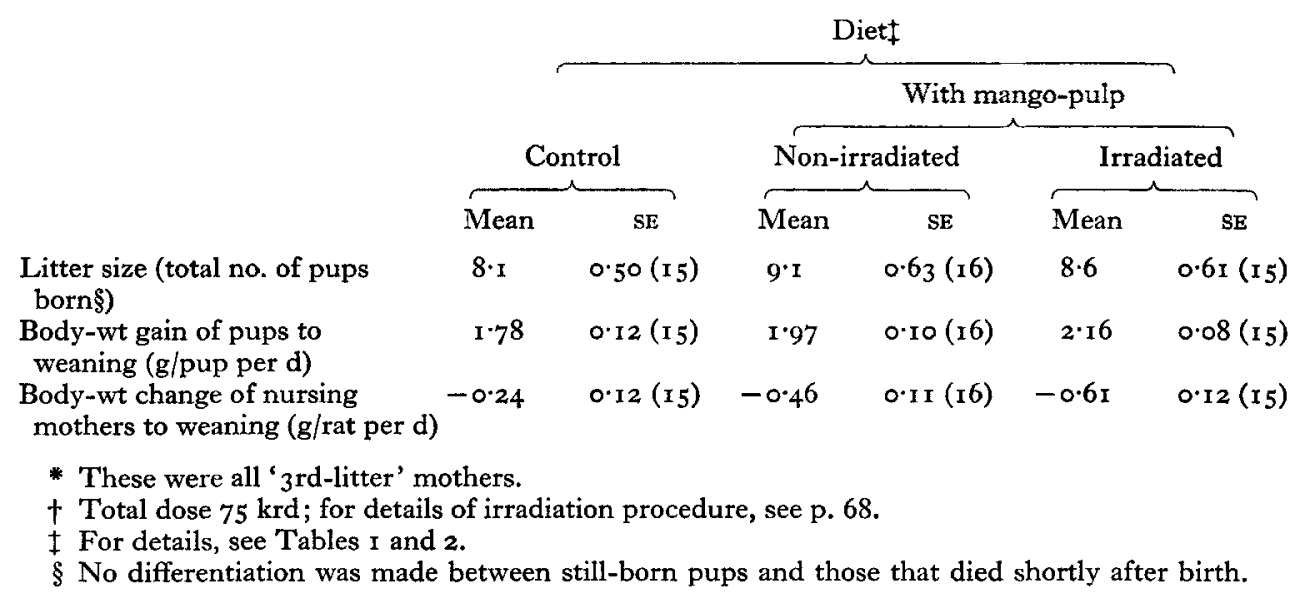

\section{RESULTS}

Digestibility and voluntary food consumption

The results of the intake and digestibility studies are given in Table 3 . Both daily food intake and DM digestibility were similar for all diets, and averaged $20.9 \mathrm{~g} \mathrm{DM}$ and 0.833 respectively. 
Table 5. Trial 3. Litter size, body-weight gain of rat pups to weaning, and body-weight gain of nursing mothers* during the $2 \mathrm{I}$ d lactation period and the 28 d postweaning period, when they were given diets with and without $15 \circ \mathrm{g}$ gamma-irradiated $\dagger$ or non-irradiated mango-pulp/kg

\begin{tabular}{|c|c|c|c|c|c|c|}
\hline & \multicolumn{6}{|c|}{ Diet $\ddagger$} \\
\hline & & & & With $\mathrm{me}$ & go-pulp & \\
\hline & \multicolumn{2}{|c|}{ Control } & \multicolumn{2}{|c|}{ Non-irradiated } & \multicolumn{2}{|c|}{ Irradiated } \\
\hline & Mean & $\mathrm{SE}$ & Mean & $\mathrm{SE}$ & Mean & SE \\
\hline $\begin{array}{l}\text { Litter size (total no. of pups } \\
\text { born§) }\end{array}$ & 10.5 & $0.63(8)$ & $9 \cdot 9$ & $0.48(\mathrm{II})$ & $9 \cdot 5$ & 0.64 (I0) \\
\hline $\begin{array}{l}\text { Body-wt gain of pups to } \\
\text { weaning (g/pup per } d \text { ) }\end{array}$ & $I \cdot 36$ & $0.09(8)$ & $I \cdot 42$ & $0.08(11)$ & $\mathrm{I} \cdot 30$ & 0.08 (10) \\
\hline $\begin{array}{l}\text { Body-wt gain of nursing } \\
\text { mothers to weaning ( } g / \text { rat per } d)\end{array}$ & $\mathrm{I} \cdot 44$ & $0.20(8)$ & $r \cdot 44$ & $0.16(I I)$ & $1 \cdot 77$ & 0.27 (10) \\
\hline $\begin{array}{l}\text { Body-wt gain of mothers during } \\
28 \mathrm{~d} \text { postweaning period } \\
\text { (g/rat per d) }\end{array}$ & 0.15 & $0.18(8)$ & 0.10 & $0.08(I I)$ & 0.06 & $0.09(10)$ \\
\hline
\end{tabular}

\section{Body-weight change}

Body-weight gains of weanling male rats during the $28 \mathrm{~d}$ postweaning period did not differ significantly, and ranged from $4 \cdot 16$ to $4.30 \mathrm{~g} / \mathrm{d}$ for the control and irradiatedmango-pulp diets respectively (Table 3 ).

In reproduction trials $I$ and 2 using ' 3 rd-litter' females, mean body-weight gains of pups to weaning at $2 \mathrm{I} \mathrm{d}$ of age ranged from $\mathrm{I} \cdot 78 \mathrm{~g} / \mathrm{d}$ for the control group to $2 \cdot \mathrm{I} 6 \mathrm{~g} / \mathrm{d}$ for the pups of females given the irradiated-mango-pulp diet (Table 4). Body-weight changes $(\mathrm{g} / \mathrm{d})$ of the nursing females during this period ranged from - $0.6 \mathrm{I}$ (irradiatedmango-pulp diet) to -0.24 (control diet).

When virgin females were used in reproduction trial 3 , the preweaning bodyweight gains of the pups ranged from $1 \cdot 30$ to $1 \cdot 42 \mathrm{~g} / \mathrm{d}$ for the irradiated- and nonirradiated-mango-pulp diets respectively. During the nursing period, all parent females continued to grow, body-weight gains averaging $1 \cdot 5^{8} \mathrm{~g} / \mathrm{d}$. The growth rate of these females for their respective dietary regimens was measured during the $28 \mathrm{~d}$ postweaning period. Body-weight gains were similar and averaged $0 \cdot 10 \mathrm{~g} / \mathrm{d}$ (Table 5).

When the results of the reproduction trials were subjected to statistical analysis, the mean values were found not to differ significantly $(P>0.05)$.

\section{Litters}

The mean number of pups born per litter in reproduction trials $\mathrm{I}$ and 2 were, for the three diets: control 8.I, non-irradiated mango-pulp 9.I, irradiated mango-pulp 8.6 (Table 4). In reproduction trial 3 , when virgin females were used, mean litter sizes for the three dietary regimens were: control $10^{\circ} 5$, non-irradiated mango-pulp 
Table 6. Haematological and blood chemistry values for weanling male rats given diets with or without $\mathrm{I}^{\circ} \mathrm{g}$ gamma-irradiated* ${ }^{*}$ or non-irradiated mango-pulp/kg, whose mothers had received the same diet during pregnancy

(Mean values with their standard errors; no. of determinations in parentheses)

\begin{tabular}{|c|c|c|c|c|c|c|}
\hline & \multicolumn{5}{|c|}{ Diet† } & \\
\hline & & & & With $\mathrm{m}$ & go-pulp & \\
\hline & \multicolumn{2}{|c|}{$\begin{array}{l}\text { Control } \\
(37)\end{array}$} & \multicolumn{2}{|c|}{$\begin{array}{c}\text { Non-irradiated } \\
\left(3^{8}\right)\end{array}$} & \multicolumn{2}{|c|}{$\begin{array}{l}\text { Irradiated } \\
\quad(39)\end{array}$} \\
\hline & Mean & SE & Mean & $\mathrm{SE}$ & Mean & SE \\
\hline $\begin{array}{l}\text { Haemoglobin concentration } \\
(\mathrm{g} / \mathrm{l})\end{array}$ & 163 & $1 \cdot 5$ & 162 & $I \cdot 2$ & $x 6 r$ & $1 \cdot 7$ \\
\hline $\begin{array}{l}\text { Erythrocyte count } \\
\left(\times 10^{12} / 1\right)\end{array}$ & $6 \cdot 75$ & 0.09 & $6 \cdot 42$ & 0.08 & $7 \cdot 12$ & 0.17 \\
\hline Packed cell volume & 0.444 & 0.0053 & 0.422 & 0.0047 & 0.447 & 0.0068 \\
\hline Mean corpuscular volume (f) & $68 \cdot 7$ & 0.23 & $68 \cdot I$ & 0.30 & $67 \cdot 2$ & 0.23 \\
\hline $\begin{array}{l}\text { Total leucocyte count } \\
\left(\times 10^{\theta} / 1\right)\end{array}$ & $16 \cdot 2$ & $\mathrm{r} \cdot \mathrm{I7}$ & $16 \cdot 6$ & 0.87 & $18 \cdot x$ & $I \cdot 44$ \\
\hline $\begin{array}{l}\text { Differential leucocyte count } \\
\text { Neutrophils } \\
\text { Lymphocytes } \\
\text { Monocytes } \\
\text { Eosinophils }\end{array}$ & $\begin{array}{l}0.118 \\
0.841 \\
0.012 \\
0.031\end{array}$ & $\begin{array}{l}0.0127 \\
0.0154 \\
0.0031 \\
0.0054\end{array}$ & $\begin{array}{l}0.121 \\
0.847 \\
0.011 \\
0.020\end{array}$ & $\begin{array}{l}0.0134 \\
0.0150 \\
0.0029 \\
0.0040\end{array}$ & $\begin{array}{l}0.109 \\
0.856 \\
0.022 \\
0.013\end{array}$ & $\begin{array}{l}0.0103 \\
0.0127 \\
0.0042 \\
0.0033\end{array}$ \\
\hline $\begin{array}{c}\text { Aspartate aminotransferase } \\
(E C \text { 2.6.I.I) }(\mathrm{mIU} \neq / \mathrm{ml})\end{array}$ & 99 & $3 \cdot 7$ & 95 & $2 \cdot 5$ & $9 \mathrm{I}$ & $3 \cdot 3$ \\
\hline Blood glucose $(\mathrm{mmol} / \mathrm{l})$ & $4 \cdot 56$ & 0.14 & $4 \cdot 58$ & $0 \cdot 16$ & $4 \cdot 58$ & 0.13 \\
\hline
\end{tabular}

9*9, irradiated mango-pulp $9 \cdot 5$ (Table 5 ). These differences were not statistically significant $(P>0.05)$ within trials.

\section{Haematology and blood chemistry}

Haematological and biochemical values for the blood of the weanling male and 'Ist-litter' female rats are given in Tables 6 and 7 respectively.

There were no deviations from the normal values for haemoglobin concentration, erythrocyte count, packed cell volume and mean corpuscular volume. There were also no significant differences between either total or differential leucocyte count, nor did the results deviate from the 'accepted' values for the rat.

For each group the values obtained for AAT, blood glucose and blood urea (reproduction trial 3 only) were within the normal range for rats.

Gross pathological examinations made on slaughtered animals did not show any morphological aberrations. 
Table 7. Haematological and blood chemistry values for parent female rats $28 d$ after weaning of the litter, when they were given diets with or without $15 \circ \mathrm{g}$ gamma-irradiated* or non-irradiated mango-pulp/kg

(Mean values with their standard errors for six rats/group)

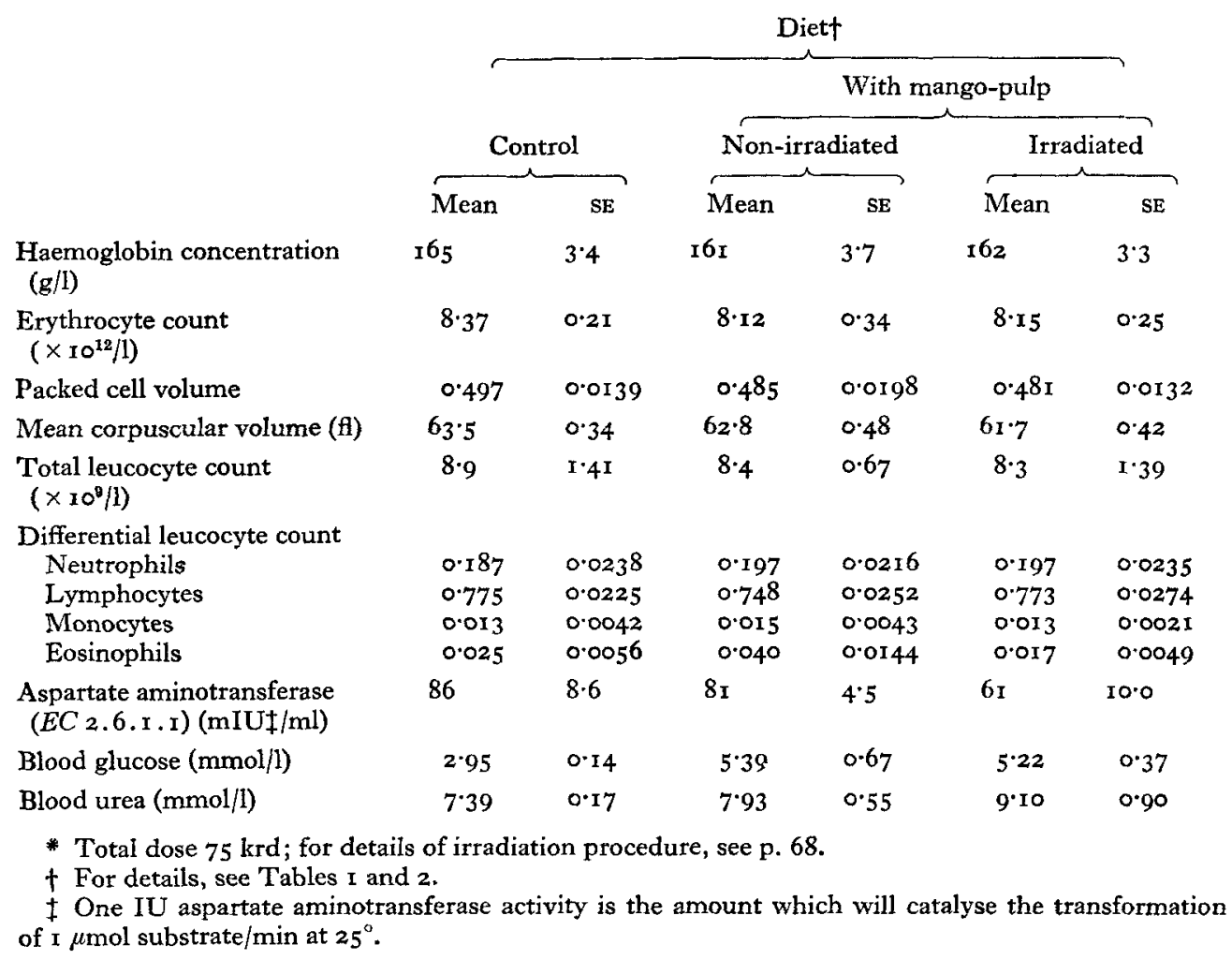

\section{DISCUSSION}

Neither voluntary food consumption nor DM digestibility were affected by the inclusion of either $150 \mathrm{~g}$ non-irradiated or irradiated mango-pulp $/ \mathrm{kg}$ in the control diet. The growth rate of weanling male rats during a $28 \mathrm{~d}$ postweaning period was similar for all dietary regimens. The mean daily body-weight gain of $4.22 \mathrm{~g}$ is satisfactory and indicates that the control diet provided the necessary nutrients required for the normal growth of the rat. Moreover, performance was not reduced by the inclusion of either non-irradiated or irradiated mango-pulp in the diet.

Body-weight changes of ' 3 rd-litter' females during the $2 \mathrm{I} \mathrm{d}$ nursing period and daily gains of pups until weaning were similar for all dietary regimens. Similarly, there were no treatment effects when virgin females were maintained on the dietary regimens for $40 \mathrm{~d}$ before mating in reproduction trial 3. Daily body-weight gains by the adult animals were similar for all diets both before and after weaning. There was, therefore, no evidence that the nutritional adequacy of the diets was impaired by the inclusion of $150 \mathrm{~g}$ non-irradiated or irradiated mango-pulp $/ \mathrm{kg}$.

No differences in haematological or blood chemistry values were found which could 
be attributed to the ingestion of irradiated mangoes. Normal values for haemoglobin concentration, erythrocyte count, packed cell volume and mean corpuscular volume indicated that there was no interference in erythropoiesis or normal erythrocyte destruction. On the basis of both total and differential leucocyte counts, the treatments had no effect on leucocyte formation or function. Normal AAT levels suggested an absence of hepatic or muscular degenerative processes. The results provided no evidence of impairment of blood-glucose control mechanisms or of renal function.

Since there was no evidence either of impairment of nutritional adequacy or of potential toxicity, it may be concluded that the wholesomeness of Kent mangoes was not affected by gamma-irradiation at a total dose of $75 \mathrm{krd}$.

The author would like to thank Professor W. L. Jenkins for comments on the manuscript, Dr R. W. Worthington for making the gross pathological examinations and Mrs M. Bezuidenhout and Mrs G. Horton for technical assistance. These studies were aided by a grant from the South African Atomic Energy Board.

\section{REFERENCES}

Association of Official Agricultural Chemists (1965). Official Methods of Analysis, roth ed. Washington, DC: Association of Official Agricultural Chemists.

Fawcett, J. K. \& Scott, J. E. (1960). F. clin. Path. 13, $5_{56}$.

Karmen, A. (1955). F. clin. Invest. 34, I3I.

National Research Council (1972). Nutrient Requirements of Laboratory Animals, 2nd ed. Washington, DC: National Academy of Sciences and National Research Council.

Read, M. S. (1960). Fedn Proc. Fedn Am. Socs exp. Biol. 19, 1055.

Reber, E. F., Raheja, K. \& Davis, D. (I966). Fedn Proc. Fedn Am. Socs exp. Biol. 25, I 529.

Snedecor, G. W. \& Cochran, W. G. (1967). Statistical Methods, 6th ed. Ames, Iowa: Iowa State University Press.

Werner, W., Rey, H. G. \& Wielinger, H. (1970). Z. analyt. Chem. 252, 224. 